\begin{tabular}{|c|l|}
\hline Title & $\begin{array}{l}\text { A new species of Tanaopsis (Crustacea: Tanaidacea) from Japan, with remarks on the functions of serial ridges and } \\
\text { grooves on the appendages }\end{array}$ \\
\hline Author(s) & KA KUI, KEIICHI; SHIMA DA, DA ISU KE \\
\hline Citation & $\begin{array}{l}\text { Zootaxa, 4282(2), 324 } \\
\text { https://doi.org/40.11646/_ootaxa.4282.2.6 }\end{array}$ \\
\hline Issue Date & 2017 \\
\hline Doc URL & http://hdl.handle.net/2115/66369 \\
\hline Type & article (author version) \\
\hline File Information & Zootaxa4282-2_324.pdf \\
\hline
\end{tabular}

Instructions for use 


\title{
A new species of Tanaopsis (Crustacea: Tanaidacea) from Japan, with remarks on the functions of serial ridges and grooves on the appendages
}

\author{
KEIICHI KAKUI ${ }^{1} \&$ DAISUKE SHIMADA ${ }^{2}$ \\ ${ }^{1}$ Faculty of Science, Hokkaido University, Sapporo 060-0810, Japan \\ E-mail:kakui@eis.hokudai.ac.jp \\ ${ }^{2}$ Department of Biology, Keio University, Yokohama 223-8521, Japan
}

Running head: A NEW TANAOPSIS FROM JAPAN

\begin{abstract}
We describe Tanaopsis japonica sp. nov. from intertidal and nearshore habitats around

Hokkaido Island, northern Japan. This species closely resembles T. chotkarakde Bird \&
\end{abstract}

Bamber, 2000 and T. rawhitia Bird, 2011 in having the uropod with the endopod biarticulate

and the exopod uniarticulate, but differs from them in the following characters: pereonite 4 as

long as pereonite 5; mandibles lacking the molar; the number of simple setae on the antenna,

propodal palm, and dactylus of pereopods 1-3; the number of spiniform setae on the cutting

surface of the chelipedal dactylus; and the number of setae on the pleopods. We also

determined a nearly complete nucleotide sequence for the $18 \mathrm{~S}$ rRNA gene in T. japonica. In

both sexes, Tanaopsis japonica sp. nov. bears serial ridges and grooves on the chela,

antennule, and antenna. Parallel, fringed hatch marks on the chelipedal dactylus may function in stridulation. A series of denticulate ridges on the dorsal surface of antennal article 2 faces the ventral side of article 1 of the antennule, where there is a ventral series of slight grooves. 
Although the ranges of motion of the antennule and antenna were unclear, the ridges and grooves on the antenna and antennule may also function in producing sound. Two outer series of ridges on the chela, together with an outer furrow on the chela, may function in digging, by allowing bottom-sediments to be efficiently pushed aside.

Key words: Peracarida, Tanaopsidae, functional morphology, adaptation, burrowing, fossorial

\section{Introduction}

The paratanaoid family Tanaopsidae Błażewicz-Paszkowycz \& Bamber, 2012 was established for the genus Tanaopsis Sars, 1899, which at the onset of our study comprised 16 species (Segadilha \& Araújo-Silva 2015). Species in Tanaopsidae are characterized by having an outer-distal bifid process on the chelipedal fixed finger and a dorsal process on the coxa of pereopod 1 (Błażewicz-Paszkowycz \& Bamber 2012; Segadilha \& Araújo-Silva 2015). Three species have been reported to date from the Northwestern Pacific: Tanaopsis curtus Kudinova-Pasternak, 1984 and T. rugaris Błażewicz-Paszkowycz et al., 2013 from the Sea of Japan at depths of 200-510 m and 455-465 m, respectively; and T. chotkarakde Bird \& Bamber, 2000 from the coast of Hong Kong (South China Sea) at the depths of 10-30 m (Kudinova-Pasternak 1984; Bird \& Bamber 2000; Błażewicz-Paszkowycz et al. 2013). 
During a survey of the shallow-water fauna along the coasts of Hokkaido Island,

northern Japan, we collected an undescribed tanaopsid species from muddy substrata at three localities (Shinhidaka, Esashi, and Otaru). In this paper, we describe and illustrate this species, present a nearly complete nucleotide sequence for the $18 \mathrm{~S}$ rRNA (18S) gene to aid future DNA barcoding and molecular phylogenetic analyses, and discuss possible functions for unusual serial ridges and grooves on this species' chela, antennule, and antenna.

\section{Materials and methods}

Samples were collected at Shinhidaka on 13 April 2013, at Esashi on 29 June 2014, and at Otaru on 27 August 2016. Geographical coordinates were obtained from Google Earth ver. 7.1 (Google Inc. 2016). At Shinhidaka and Esashi, roots of the seagrass Phyllospadix iwatensis Makino laden with muddy sand were collected by hand from intertidal rocky shore; at Otaru, muddy sand accumulated among rocks was collected by SCUBA diving at a depth of $3 \mathrm{~m}$. Collected substrata were washed in tap water; the supernatant was then filtered through 0.063 or $0.315 \mathrm{~mm}$ mesh and tanaidaceans were picked from the residue. The type specimens were fixed in $70 \%$ ethanol and preserved in $99 \%$ ethanol, and were deposited in the Invertebrate Collection of the Hokkaido University Museum (ICHUM). The methods used in dissection, specimen preparation, light microscopy, scanning electron microscopy (SEM), and drawing were as described in Kakui \& Angsupanich (2012). 
Orientation and terminology here follow Larsen (2003), except that the term “plumose sensory seta(e)" (PSS; Bird 2011) is used instead of "broom seta(e)". Body length (BL) and cephalothorax length were measured from the base of the antennules to the tip of the pleotelson and the posterior edge of the carapace, respectively; body width was measured at the widest portion of the carapace (carapace width; CW). Measurements were made axially: dorsally on the body, antennules, antennae, and uropods; laterally on the pereopods and pleopods. The appendages were measured in holotype and allotype specimens. All measurements in the text are in millimeters, unless noted otherwise. Length and width in congeners were measured from original illustrations.

Total DNA was extracted from the left cheliped of the paratype specimen by using a DNeasy Blood \& Tissue Kit (Qiagen, Germany); after extraction, the exoskeleton was recovered and mounted on a slide. The $18 \mathrm{~S}$ gene was amplified by PCR in overlapping fragments, and the nearly complete $18 \mathrm{~S}$-gene sequence was determined. Table 1 lists the primers used in PCR and cycle sequencing. The PCR amplification condition with KOD FX Neo polymerase (Toyobo, Japan) was $94^{\circ} \mathrm{C}$ for $2 \mathrm{~min} ; 45$ cycles of $98^{\circ} \mathrm{C}$ for $10 \mathrm{~s}, 52^{\circ} \mathrm{C}$ for 30 $\mathrm{s}$, and $68^{\circ} \mathrm{C}$ for $90 \mathrm{~s}$; and $68^{\circ} \mathrm{C}$ for $4 \mathrm{~min}$. Nucleotide sequences were determined by direct sequencing with a BigDye Terminator Kit ver. 3.1 and a 3130 Genetic Analyzer (Life Technologies, USA), and segments were joined into a single sequence by using MEGA 5.2 (Tamura et al. 2011). The nearly complete sequence of $18 \mathrm{~S}$ gene we obtained was deposited 
in the International Nucleotide Sequence Database (INSD) through the DNA Data Bank of Japan (DDBJ).

\section{Systematics}

Family Tanaopsidae Błażewicz-Paszkowycz \& Bamber, 2012

Genus Tanaopsis Sars, 1899

Tanaopsis japonica sp. nov.

Figures $1-8$

Material examined. Holotype. Female without developed or developing oostegites,

ICHUM-5339 (BL 1.43, CW 0.32), 9 slides, 1 vial, and 1 SEM stub; Asari-hama (Asari beach), Higashi-shizunai, Shinhidaka, Hokkaido, Pacific Ocean, $42^{\circ} 17.173 ' \mathrm{~N}, 142^{\circ} 27.683^{\prime} \mathrm{E}$, muddy sand around roots of the seagrass Phyllospadix iwatensis, intertidal zone, 13 April 2013, coll. by D. Shimada.

Allotype. Male, ICHUM-5340 (BL 1.44, CW 0.32), 6 slides and 1 vial;

Kamome-jima (Kamome Island), Esashi, Hokkaido, Sea of Japan, 41ํ52.198'N, $140^{\circ} 6.958^{\prime} \mathrm{E}$, muddy sand around roots of the seagrass Phyllospadix iwatensis, intertidal zone, 29 June 2014, coll. by A. Shibata.

Paratype. Female without developed or developing oostegites, ICHUM-5341 (BL 
1.75, CW 0.32), 5 slides, 1 vial, and 1 SEM stab; INSD accession number LC210598; Oshoro,

Otaru, Hokkaido, Sea of Japan, $43^{\circ} 12.886^{\prime} \mathrm{N}, 140^{\circ} 51.304^{\prime} \mathrm{E}$, muddy sand, 3 m, SCUBA, 27

August 2016, coll. by K. Kakui.

Diagnosis. Pereonites 4 and 5 subequal in length (length ratio of pereonites 4/5 1.0);

mandibular molar absent; uropod with biarticulate endopod and uniarticulate exopod.

Etymology. The specific name is an adjective referring to the type locality.

Description of female. Based on holotype.

Body (Fig. 1A, a1-3) dorsoventrally flattened, 4.4 times as long as CW, translucent, slightly yellowish when alive (Fig. 8). Cephalothorax 0.2 times as long as BL, 0.9 times as long as wide, trapezoidal, with pair of lateral simple setae; eye lobes absent. Pereonites 1-6 with length ratio of 1.0:1.1:1.4:1.9:1.9:1.3; all wider than long, with one or two pairs of simple setae. Pleon 0.3 times as long as BL. Pleonites slightly wider than pereonite 6; all wider than long, similar in shape, with slight lamellar lateral projection (Figs 1a3, 8), and ventral keel (Fig. 1a3); pleonite 5 with two pairs of simple setae. Pleotelson 0.6 times as long as wide, narrower than pleonites, with pair of simple setae proximal to uropodal insertion, pair of simple setae and pair of PSS in subdistal region, and pair of simple setae in distal region.

Antennule (Fig. 2A) 0.9 times as long as cephalothorax; articles 1-4 with length ratio of 1.0:0.5:0.3:0.6. Article 1 with two distal simple setae, several PSS, and series of 
ventroproximal slight grooves (Fig. 7D-F). Article 2 with two distal simple setae and several distal PSS. Article 3 with two distal simple setae. Article 4 with cap-like vestigial article (Fig. 6A), five simple setae and aesthetasc. Antenna (Fig. 2B, C) with six articles, 0.9 times as long as antennule; articles 1-6 with length ratio of 0.4:1.0:0.7:2.0:0.8:0.3. Article 1 naked. Article 2 with inner distal simple seta and series of dorsal denticulate ridges (Figs 2C, 7A, B). Article 3 with inner distal simple seta. Article 4 with three distal simple setae and one mid-inner and several distal PSS. Article 5 with distal simple seta. Article 6 with six distal simple setae.

Labrum (Fig. 2D) naked. Mandibles (Fig. 2E, F) without molar. Incisor of left mandible (Fig. 2E) with blunt tooth and several small teeth; lacinia mobilis widening distally, with several small teeth. Incisor of right mandible (Fig. 2F) with blunt tooth and several smaller teeth. Labium (Fig. 2G) naked. Maxillule (Fig. 2H) endite with one thicker and three thinner spines; palp lost during dissection. Maxilla lost during dissection. Maxillipeds (Fig. 2I) with bases, each bearing simple seta at insertion of palp; distal half of bases separated. Endites flared, separated, reaching beyond distal margin of palp article 1, each with simple seta. Palp article 1 naked; article 2 with two inner and one outer simple setae; article 3 with two inner simple setae; article 4 with three simple and three pinnate setae. Epignath (Fig. 2J) narrow, curved, naked.

Cheliped (Figs 3A, a1, a2, B, 6B-E) with triangular articulation with cephalothorax via sclerite (Figs 1a1, 3A, 6B). Basis slightly longer than wide, with free posterior portion 
and dorsal simple seta. Merus with ventral simple seta. Carpus 1.5 times as long as wide, with one dorsomedial, one dorsodistal, and two ventral simple setae. Chela as long as carpus; propodal palm as long as fixed finger, with one outer, one longer inner, and three shorter inner simple setae at insertion of dactylus (Fig. 3a1); fixed finger with two simple setae on ventral margin, three simple setae on cutting surface, series of outer smooth ridges (Fig. 6C, D: black arrowheads), outer distal bifurcate process, and bifurcate claw; dactylus as long as fixed finger, with inner simple seta, three spiniform setae on cutting surface, series of denticulate outer dorsal ridges (Fig. 6C-E: white arrowheads), inner hatching with fringed incisions (Fig. 6C-E: arrows), and triangular claw.

Pereopods 1-6 cylindrical, with length ratio of 1.5:1.1:1.0:1.0:1.0:1.0. Pereopod 1 (Fig. 3C, D) 0.4 times as long as BL, with length ratio of basis, ischium, merus, carpus, propodus, and dactylus-unguis 4.5:0.4:1.0:1.4:2.9:3.7. Coxa with dorsal simple seta and acute dorsal process. Basis cylindrical, narrow (4.5 times as long as wide), naked. Ischium with ventral simple seta. Merus naked. Carpus with three dorsodistal and one ventrodistal simple setae. Propodus serrated dorsally, with three dorso-subdistal and one ventro-subdistal setae, and dorsodistal serrations. Dactylus with dorsoproximal simple seta. Unguis twice as long as dactylus, naked. Pereopod 2 (Fig. 3E) with length ratio of articles from basis to dactylus-unguis 5.1:0.4:1.0:1.5:3.1:3.6; similar to pereopod 1, except coxa without dorsal process, basis with one dorsal PSS, carpus with two dorsodistal simple setae, and propodus 
with two dorso-subdistal setae. Pereopod 3 (Fig. 3F) with length ratio of articles from basis to dactylus-unguis 5.3:0.5:1.0:1.4:3.2:3.1; similar to pereopod 2, except basis with one ventral PSS. Pereopod 4 (Fig. 3G) without coxa. Length ratio of articles from basis to dactylus-unguis 3.5:0.3:1.0:1.3:1.7:1.7. Basis thick (2.5 times as long as wide), with one dorsal PSS. Ischium with ventral simple seta. Merus with one outer and one inner serrate-spiniform setae in ventrodistal region. Carpus with dorsodistal simple seta, and one outer and two inner serrate-spiniform setae in distal region. Propodus with one dorsal PSS, dorsal serrations on edge in distal half, and one dorsodistal, one outer ventrodistal, and one inner ventrodistal pinnate-spiniform setae. Dactylus naked. Unguis 0.6 times as long as dactylus. Pereopod 5 (Fig. 3H) with length ratio of articles from basis to dactylus-unguis 2.7:0.2:1.0:1.1:1.6:1.4; similar to pereopod 4 except basis with two dorsal and one ventral PSS, and ischium with two ventral simple setae. Pereopod 6 (Fig. 3I, i1) with length ratio of articles from basis to dactylus-unguis 3.0:0.3:1.0:1.0:1.5:1.1; similar to pereopod 4 except propodus with two dorsodistal serrate setae (Fig. 3i1) but lacking dorsal PSS.

Pleopods (Fig. 3J) five pairs, all similar. Basal article naked. Endopod 2.2 times as long as basal article, with one inner subdistal and five outer plumose setae, and outer distal "step-tipped plumose seta" (see Kakui et al. 2010: fig. 5j2). Exopod 1.3 times as long as endopod, with 17-20 outer plumose setae; "vestigial proximal article" (see Bird 2012) with outer plumose seta. 
Uropod (Fig. 3K) with basal article naked. Endopod 2.5 times as long as basal article, biarticulate; article 1 with length/width ratio 1.7, with one distal PSS; article 2 as long as article 1, with one subdistal and four distal simple setae, and two distal PSS. Exopod uniarticulate, slightly shorter than endopodal article 1, with one subdistal and two distal simple setae.

Description of male. Based on allotype.

Body (Fig. 1B, b1-4) similar to female but pleon proportionally longer. Pereonites 1-6 with length ratio of 1.0:1.2:1.7:2.4:2.3:1.5; all wider than long; pereonite 6 with pair of genital cones (Fig. 1b2). Pleon 0.4 times as long as BL.

Antennule (Fig. 4A) as long as cephalothorax, with six articles; thicker than that of female; articles 1-6 with length ratio of 1.0:0.4:0.1:0.1:0.2:0.2. Setation of articles 1-3 similar to those of female. Articles 4 and 5 with ventrodistal row of aesthetascs. Article 6 with six simple setae and aesthetasc; cap-like vestigial article not observed. Antenna (Fig. 4B) 0.8 times as long as antennule, similar to that of female except article 4 with two mid-outer PSS, and articles 5 and 6 with two and four distal simple setae, respectively.

Mouthparts (Fig. 4C-E) reduced. Vestigial labrum (Fig. 4C: arrowhead) observed. Labium (Fig. 4D) narrowing distally, naked. Maxillipeds (Fig. 4E) similar to those of female, except endites not flared and all setae on palp-article 4 simple.

Cheliped (Fig. 4F, f1, G) similar to that of female, except propodal palm with six 
shorter inner simple setae at insertion of dactylus, fixed finger with outer distal trifurcate process, and dactylus with two spiniform setae on cutting surface.

Pereopods 1-6 (Fig. 5A-F) with length ratio of 1.4:1.1:1.0:1.1:1.1:1.1 (note that pereopod-6 unguis broken); pereopod 1 length 0.38 times BL. Pereopods similar to those of female, but differ as follows: coxa of pereopod 1 without acute dorsal process; basis of both pereopods 4 and 5 with two ventral PSS; ischium of pereopods 4 and 6 with two ventral simple setae; carpus of pereopods 4-6 with two dorsodistal simple setae.

Pleopods (Fig. 5G) five pairs, all similar. Basal article naked. Endopod 1.8 times as long as basal article, with five longer and one shorter outer plumose setae, and one inner subdistal and one outer distal step-tipped plumose setae. Exopod 1.2 times as long as endopod, with 10-14 outer plumose setae; vestigial proximal article naked.

Uropod (Fig. 5H) similar to that of female, except endo- and exopod proportionally shorter (endopod twice as long as basal article) and endopodal article 2 with two distal simple setae.

Variation and stability. One additional female (paratype) was observed. The ratio of BL/CW was different among specimens, i.e., 4.4 (female holotype; BL 1.43), 4.5 (allotype; BL 1.44), and 5.5 (paratype; BL 1.75), but pereonites 4 and 5 were subequal in length in all specimens, i.e., the length ratio of pereonites $4 / 5$ was 1.0 . In the two females, the numbers of simple, spiniform, serrate-spiniform, pinnate-spiniform, and serrate setae on the antenna, 
cheliped, and pereopods were constant. The number of setae on the pleopodal endopod was constant among the five pairs in each specimen and between the two females; that on the exopod varied, ranging from 16 to 18 in the paratype. All specimens lacked setae on the basal article of all pleopods. All specimens had a biarticulate uropodal endopod.

Genetic Information. The nearly complete $18 \mathrm{~S}$-gene sequence (2275 nt) was determined from the paratype specimen; INSD accession number LC210598. The three sequences in the International Nucleotide Sequence Database most similar to our sequence, as determined by BLAST searches (Altschul et al. 1990), were from the tanaidaceans Chauliopleona sp. KK-2011 (identity score [IS] 97\%; query cover [QC] 65\%;

Akanthophoreidae; Kakui et al. 2011), Paratanais sp. KK-2011 (IS 98\%; QC 63\%;

Paratanaidae; Kakui et al. 2011), and Paratanais malignus Larsen, 2001 (IS 98\%; QC 66\%;

Paratanaidae; Spears et al. 2005).

Distribution. So far known only from three localities around Hokkaido Island, at depths of $0-3 \mathrm{~m}$.

Remarks. Tanaopsis japonica sp. nov. is the seventeenth species described in this genus and family. In having the uropod with the endopod biarticulate and the exopod uniarticulate, this species closely resembles $T$. chotkarakde Bird \& Bamber, 2000 from around Hong Kong and T. rawhitia Bird, 2011 from New Zealand waters (Bird \& Bamber 2000; Bird 2011). Female T. japonica differs from T. chotkarakde in the following characters 
(character state of T. chotkarakde in parentheses): the length ratio of pereonites $4 / 5$ is 1.0

(1.2); antennal article 4 has three simple distal setae (two); the propodal palm of the cheliped has one longer and three shorter inner simple setae at the insertion of the dactylus (one longer and two shorter setae); the chelipedal dactylus has three spiniform setae on the cutting surface (one); and the pleopodal basis is naked (one outer seta) (Bird \& Bamber 2000). Males have not yet been described for T. chotkarakde.

Tanaopsis japonica differs from T. rawhitia as follows (character state of the latter in parentheses). In both sexes, $T$. japonica has the dactylus of pereopods $1-3$ with a dorsoproximal simple seta (naked). In females, the mandible lacks a molar (point-tipped molar present); pereonites 4 and 5 are all wider than long (as wide as long), antennal article 2 lacks outer setae (one outer seta), and the pleopodal endopod has six outer setae in total (eight or nine). In males, T. japonica has the antennule with six articles bearing two rows of aesthetascs (seven articles and three rows), the propodal palm of the cheliped has one longer and six shorter inner simple setae at the insertion of the dactylus (two longer and 11 shorter setae), and the uropodal exopod is uniarticulate (biarticulate) (Bird 2011).

Our male specimen of $T$. japonica is unique within Tanaopsidae in that its antennule consists of six articles and bears two rows of aesthetascs. Including male T. laticaudata (Sars, 1882) sensu Sars (1886), which Lang (1967: p. 350) suggested might have been misidentified as to genus, males have previously been reported in nine congeners, all of which have 
seven-articulate antennule with three rows of aesthetascs (Sars 1886; Lang 1967; Shiino 1970; Kudinova-Pasternak 1984; Sieg \& Dojiri 1991; Bird 2011; Segadilha \& Araújo-Silva 2015). To determine whether the six-articulate antennule is restricted to T. japonica, males must be examined from additional species.

Among congeners, T. cadieni Sieg \& Dojiri, 1991 and T. gallardoi (Shiino, 1970) include descriptions of the male mouthparts. Although the maxillipedal endites are flared in these species, they are not flared in male T. japonica. While Shiino (1970) observed mandibles in male T. gallardoi, we found only a simple opening in place of the mandibles (Fig. 4C). This suggests that, as observed in Nototanoides (Nototanaidae; Kakui \& Yamasaki 2013), the degree of reduction of the male mouthparts can vary among species in Tanaopsis.

\section{Discussion: possible functions of the serial structures on appendages}

We observed that Tanaopsis japonica, in both sexes, has series of ridges or grooves on the chela, antennule, and antenna. On the chelipedal dactylus, there is inner dorsal hatching with fringed incisions (Fig. 6C-E: arrows) and a series of outer dorsal denticulate ridges (Fig. 6CE: white arrowheads), and on the fixed finger there is a series of outer smooth ridges (Fig.

6C-E: black arrowheads); the antennule has a ventral series of slight grooves on article 1 (Fig. 7C-F); and the antenna bears a series of dorsal denticulate ridges on article 2 (Fig. 7A, B). The inner dorsal hatching with fringed incisions was present on both chelae, and was 
similar in position to that on the male chelipedal dactyli in Nesotanais (Nototanaidae; Kakui et al. 2010). In T. japonica, hatched zones on the right and left chelipedal dactyli are opposed to one another in situ (Fig. 8), as in Nesotanais. A similarly paired series of structures on the chelipedal dactyli occurs in decapods (e.g., Guinot-Dumortier \& Dumortier 1960; Forest 1995) and functions as a stridulating organ to produce acoustic signals (Boon et al. 2009). It will be necessary to observe behavior in T. japonica to confirm whether the hatching in this species likewise functions in stridulation.

The series of denticulate ridges on article 2 of the antenna have previously been illustrated in four congeners (T. antarctica Lang, 1967, T. gallardoi, T. oios Błażewicz-Paszkowycz \& Bamber, 2012, and T. profunda Lang, 1967), but no possible functions were proposed (Lang 1967; Shiino 1970; Błażewicz-Paszkowycz \& Bamber 2012). We observed that the ridges located in the dorsal region of the antenna face toward the ventral surface of the antennule in situ (Fig. 7D-F). As mentioned above, a series of slight grooves is distributed ventrally on antennular article 1. A paired relationship between the serial structures on the antenna and those on antennule in palinuid lobsters functions to produce squeaking sounds through a frictional "stick-and-slip" mechanism (Patek 2001, 2002). This mechanism likely does not apply to $T$. japonica, where the two appendages are covered by hard exoskeleton. However, the nearly face-to-face relationship suggests that the series of ridges and grooves on those appendages may function to produce sound by stridulation. 
Behavioral observations, or at least elucidation of the ranges of motion of the antennule and antenna, will be needed to verify this.

An outer series of ridges on the chelae is not uncommon among paratanaoid tanaidaceans, occurring in various families, including Anarthruridae, Akanthophoreidae, Tanaellidae, and Tanaopsidae (e.g., Lang 1967; Sieg 1986; Bird 2004;

Błażewicz-Paszkowycz \& Bamber 2012). To our knowledge, reasonable functions for these structures have not previously been proposed. Tanaopsis japonica likewise has two outer series of ridges (Fig. 6C, D: black and white arrowheads). The outer surface of the propodal palm is transversely depressed (Fig. 6C) and is correlated with a concavity between the two series of ridges. This produces a continuous furrow that runs along the outer series of ridges, from the distal tip to the proximal portion of the chela, and is similar in shape to the blade of a shovel facing outwards (Fig. 6C). This scoop-shaped morphology occurs in the distal part of the forelimbs in various burrowing animals such as moles (Talpidae; cf. Edwards 1937) and mole crickets (Gryllotalpidae; cf. Sharp 1895: fig. 206 in p. 333), and is considered to be morphological adaptation for digging (Sharp 1895; Edwards 1937). The similarly scoop-shaped outer surface of the chelae in $T$. japonica may likewise be an adaptation for digging, or for efficiently pushing aside bottom sediments. To test whether this is the case, observations of burrowing behavior in T. japonica and other tanaidaceans with similar chela morphology will be necessary. 


\section{Acknowledgments}

We thank Shinri Tomioka (Hokkaido University; HU) for help in sampling by SCUBA and discussion on the possible function of the series of outer ridges on the chela; Akiho Shibata (HU) and Koji Shibazaki (HU) for help in sampling; Tomoyuki Komai (Natural History Museum and Institute, Chiba) for information on stridulating organs in decapods; and Matthew H. Dick (HU) for reviewing and editing the manuscript. This work was supported in part by a KAKENHI grant (JP16K18597) from the Japan Society for Promotion of Science (JSPS).

\section{References}

Altschul, S.F., Gish, W., Miller, W., Myers, E.W. \& Lipman, D.J. (1990) Basic local alignment search tool. Journal of Molecular Biology, 215, 403-410.

Bird, G.J. (2004) Tanaidacea (Crustacea) of the Northeast Atlantic: non-filiform species of Anarthruridae Lang from the Atlantic Margin. Zootaxa, 471, 1-44.

Bird, G.J. (2011) Paratanaoidean tanaidaceans (Crustacea: Peracarida) from littoral and shallow sublittoral habitats in New Zealand, with descriptions of three new genera and seven new species. Zootaxa, 2891, 1-62.

Bird, G.J. (2012) A new leptochelioid family, Heterotanoididae (Crustacea: Peracarida: 
Tanaidacea), and a new species of Heterotanoides from New Zealand. Zootaxa, 3481, 1-

26.

Bird, G.J. \& Bamber, R.N. (2000) Additions to the tanaidomorph Tanaidacea (Crustacea: Peracarida) of Hong Kong. In: Morton, B. (Ed.), The Marine Flora and Fauna of Hong Kong and Southern China V. Hong Kong University Press, Hong Kong, pp. 65-104.

Błażewicz-Paszkowycz, M. \& Bamber, R.N. (2012) The shallow-water Tanaidacea (Arthropoda: Malacostraca: Peracarida) of the Bass Strait, Victoria, Australia (other than the Tanaidae). Memoirs of Museum Victoria, 69, 1-235.

Błażewicz-Paszkowycz, M., Bamber, R.N. \& Jóźwiak, P. (2013) Tanaidaceans (Crustacea: Peracarida) from the SoJaBio joint expedition in slope and deeper waters in the Sea of Japan. Deep-Sea Research II, 86-87, 181-213.

Boon, P.Y., Yeo, D.C.J. \& Todd, P.A. (2009) Sound production and reception in mangrove crabs Perisesarma spp. (Brachyura: Sesarmidae). Aquatic Biology, 5, 107-116.

Edwards, L.F. (1937) Morphology of the forelimb of the mole (Scalops aquaticus, L.) in relation to its fossorial habits. Ohio Journal of Science, 37, 20-41.

Forest, J. (1995) Crustacea Decapoda Anomura: revision du genre Trizopagurus Forest, 1952 (Diogenidae), avec l'établissement de deux genres nouveaux. Mémoires du Muséum National d'Histoire Naturelle, 163, 9-149.

Google Inc. (2016) Google Earth ver. 7.1. Available from: http://www.google.com/earth/ 
(Accessed on 1 December, 2016).

Guinot-Dumortier, D. \& Dumortier, B. (1960) La stridulation chez les crabes. Crustaceana, 1, $117-155$.

Kakui, K. \& Angsupanich, S. (2012) Birdotanais songkhlaensis, a new genus and species of Nototanaidae (Crustacea: Tanaidacea) from Thailand. Raffles Bulletin of Zoology, 60, $421-432$.

Kakui, K., Kajihara, H. \& Mawatari, S.F. (2010) A new species of Nesotanais Shiino, 1968 (Crustacea, Tanaidacea) from Japan, with a key to species and a note on male chelipeds. ZooKeys, 33, 1-17.

Kakui, K. Katoh, T., Hiruta, S.F., Kobayashi, N. \& Kajihara, H. (2011) Molecular systematics of Tanaidacea (Crustacea: Peracarida) based on $18 \mathrm{~S}$ sequence data, with an amendment of suborder/superfamily-level classification. Zoological Science, 28, 749-757.

Kakui, K. \& Yamasaki, H. (2013) Nototanaids (Crustacea: Tanaidacea) from Japan, with the description of a new species of Nototanoides. Species Diversity, 18, 245-254.

Kudinova-Pasternak, R.K. (1984) The Tanaidacea (Crustacea: Malacostraca) of the Sea of Japan. Zoologicheskii Zhurnal, 63, 828-838. [in Russian with English abstract]

Lang, K. (1967) Taxonomische und phylogenetische Untersuchungen über die Tanaidaceen. 3. Der Umfang der Familien Tanaidae Sars, Lang und Paratanaidae Lang nebst Bemerkungen über den taxonomischen Wert der Mandibeln und Maxillulae. Dazu eine 
taxonomisch-monographische Darstellung der Gattung Tanaopsis Sars. Arkiv för Zoologi, 19, 343-368, 1 plate.

Larsen, K. (2001) Morphological and molecular investigation of polymorphism and cryptic species in tanaid crustaceans: implications for tanaid systematics and biodiversity estimates. Zoological Journal of the Linnean Society, 131, 353-379.

Larsen, K. (2003) Proposed new standardized anatomical terminology for the Tanaidacea (Peracarida). Journal of Crustacean Biology, 23, 644-661.

Patek, S.N. (2001) Spiny lobsters stick and slip to make sound. Nature, 411, 153-154.

Patek, S.N. (2002) Squeaking with a sliding joint: mechanics and motor control of sound production in palinurid lobsters. Journal of Experimental Biology, 205, 2375-2385.

Sars, G.O. (1882) Revision af gruppen: Isopoda chelifera med charakteristik af nye herhen hørende arter og slægter. Archiv for Mathematik og Naturvidenskab, 7, 1-54.

Sars, G.O. (1886) Nye bidrag til kundskaben om Middelhavets invertebratfauna. III. Middelhavets Saxisopoder (Isopoda chelifera). Archiv for Mathematik og Naturvidenskab, 11, 263-368, 15 plates.

Sars, G.O. (1899) An account of the Crustacea of Norway with Short Descriptions and Figures of All the Species. Vol. II Isopoda. Bergen Museum, Bergen. x + 270 pp., 100 plates, 4 supplemental plates.

Segadilha, J.L. \& Araújo-Silva, C.L. (2015) Two new species of Tanaopsis (Tanaidacea: 
Tanaopsidae) from Admiralty Bay (Antarctica), with an identification key. Nauplius, 23, $31-45$.

Sharp, D. (1895) Insecta. In: Harmer, S.F. \& Shipley, A.E. (Eds), Cambridge Natural History 5. MacMillan, London, pp. 81-565.

Shiino, S.M. (1970) Paratanaidae collected in Chile Bay, Greenwich Island by the XXII Chilean Antarctic Expedition, with an Apseudes from Porvenir Point, Tierra del Fuego Island. Instituto Antartico Chileno Serie Cientifica, 1, 77-122.

Sieg, J. (1986) Tanaidacea (Crustacea) von der Antarktis und Subantarktis. II. Tanaidacea gesammelt von Dr. J. W. Wägele während der Deutschen Antarktis Expedition 1983. Mitteilungen aus dem Zoologischen Museum der Universität Kiel, 2, 1-80.

Sieg, J. \& Dojiri, M. (1991) Two new species and a new genus of the suborder Tanaidomorpha (Crustacea: Tanaidacea) from Californian waters. Journal of Natural History, 25, 1493-1512.

Spears, T., DeBry, R.W., Abele, L.G. \& Chodyla, K. (2005) Peracarid monophyly and interordinal phylogeny inferred from nuclear small-subunit ribosomal DNA sequences (Crustacea: Malacostraca: Peracarida). Proceedings of the Biological Society of Washington, 118, 117-157.

Tamura, K. Peterson, D., Peterson, N., Stecher, G., Nei, M. \& Kumar, S. (2011) MEGA5: Molecular evolutionary genetics analysis using maximum likelihood, evolutionary 
distance, and maximum parsimony methods. Molecular Biology and Evolution, 28,

$2731-2739$.

\section{Figure legends}

FIGURE 1. Tanaopsis japonica $\mathbf{s p . ~ n o v . ~ A , ~ h o l o t y p e ~ f e m a l e ; ~} \mathbf{B}$, allotype male: A, B, body, dorsal view; a1, b1, body, left view; a2, b3, pleonite 5 and pleotelson, dorsal view; b2, genital cones on pereonite 6 , ventral view; a3, b4, pereonite 6 and pleon, left view. Scale bars: $0.5 \mathrm{~mm}$.

FIGURE 2. Tanaopsis japonica sp. nov., holotype female: A, left antennule; B, left antenna; C, proximal region of right antenna; D, labrum; E, F, left and right mandibles; G, labium; H, distal part of left maxillule; I, maxillipeds; J, right epignath. Scale bars: $0.1 \mathrm{~mm}$.

FIGURE 3. Tanaopsis japonica sp. nov., holotype female: A, right cheliped, outer view; a1, same, chela, inner view; a2, same, distal region of fixed finger, outer view; $\mathbf{B}$, left chelipedal dactylus; C, D, right and left pereopods 1, respectively, outer views; $\mathbf{E}$, left pereopod 2, outer view; F, left pereopod 3, inner view; G-I, right pereopods 4-6, respectively, outer view; i1, serrate seta; J, right pleopod 1, most setal ornamentation omitted; $\mathbf{K}$, right uropod. Scale bars: $0.05 \mathrm{~mm}$ for a2, B, i1; $0.1 \mathrm{~mm}$ for the others. 
FIGURE 4. Tanaopsis japonica sp. nov., allotype male: A, right antennule; B, right antenna; C, anterior region of cephalothorax, left view; D, labium, ventral view; E, maxillipeds; F, right cheliped, outer view; f1, same, distal region of fixed finger, outer view; $\mathbf{G}$, left cheliped, inner view. Scale bars: $0.1 \mathrm{~mm}$ for A-D, F, G; $0.05 \mathrm{~mm}$ for E, f1.

FIGURE 5. Tanaopsis japonica sp. nov., allotype male: A-F, right pereopods 1-6, respectively, outer view; $\mathbf{G}$, right pleopod 1, most setal ornamentation omitted; $\mathbf{H}$, right uropod. Scale bars: $0.1 \mathrm{~mm}$.

FIGURE 6. Tanaopsis japonica sp. nov., paratype female, scanning electron microscopic images: A, terminal region of antennule, with double arrowhead indicating vestige of small cap-like article; B, cheliped-sclerite-cephalothorax connection, right view, with asterisk indicating acute dorsal process on pereopod-1 coxa (other parts were detached); $\mathbf{C}-\mathbf{E}$, right chela, anterior $(\mathbf{C})$, outer $(\mathbf{D})$, and inner dorsal (E) views, with each white arrowhead indicating one ridge in outer series of denticulate ridges on dactylus, each black arrowhead indicating one ridge in series of smooth ridges on fixed finger, and each arrow indicating one fringed incision in inner hatching on dactylus; inserts in (D) and (E) are images magnified threefold from the corresponding boxes in the main panels. Scale bars: $0.01 \mathrm{~mm}$ for A; 0.05 
$\mathrm{mm}$ for B-E.

FIGURE 7. Tanaopsis japonica sp. nov. A, B, holotype female; C-F, paratype female; scanning electron microscopic images: A, part of right antenna, dorsal view, showing series of denticulate ridges on article 2; B, enlargement of ridges from (A); C, cephalothorax, anterior ventral view (left cheliped and antenna removed); D, E, proximal region of antennule and antenna in right view and right anterior ventral view, respecively; $\mathbf{F}$, enlargement from (E) showing grooves and ridges. Each white arrowhead, dorsal denticulate ridge on antenna article 2; each black arrowhead, ventral groove on antennule article 1 . Scale bars: $0.01 \mathrm{~mm}$ for $\mathrm{A}, \mathrm{B}, \mathrm{F} ; 0.1 \mathrm{~mm}$ for $\mathrm{C}, \mathrm{E} ; 0.05 \mathrm{~mm}$ for $\mathrm{D}$.

FIGURE 8. Living female Tanaopsis japonica sp. nov. (paratype). Scale bar: $0.5 \mathrm{~mm}$. 
Table 1. List of PCR and cycle sequencing (CS) primers used in this study.

\begin{tabular}{|c|c|c|c|}
\hline Primer & Sequence (5' to $\left.3^{\prime}\right)$ & Reaction & Source \\
\hline $18 \mathrm{~S}-\mathrm{a} 1 \mathrm{~F}$ & GGYGAAACCGYGAAWGGYTC & PCR & Kakui et al. (2011) \\
\hline $18 \mathrm{~S}-\mathrm{b} 3 \mathrm{~F}$ & CCTGAGAAACGGCTACCACAT & CS & This study \\
\hline 18S-b4R & TCCAACTACGAGCTTTTTAACC & $\mathrm{CS}$ & Kakui et al. (2011) \\
\hline $18 \mathrm{~S}-\mathrm{b} 6 \mathrm{~F}$ & CCTGCGGCTTAATTTGACTC & CS & Kakui et al. (2011) \\
\hline 18S-a6R & AACGGCCATGCACCAC & $\mathrm{CS}$ & Kakui et al. (2011) \\
\hline $18 \mathrm{~S}-\mathrm{b} 8 \mathrm{R}$ & TCTAAGGGCATCACAGACCTG & $\mathrm{CS}$ & Kakui et al. (2011) \\
\hline $18 \mathrm{~S}-\mathrm{b} 8 \mathrm{~F}$ & GGTCTGTGATGCCCTTAGATG & $\mathrm{CS}$ & Kakui et al. (2011) \\
\hline $18 \mathrm{~S}-\mathrm{a} 9 \mathrm{R}$ & CCTTGTTACGACTTTTAGTTCC & PCR & Kakui et al. (2011) \\
\hline
\end{tabular}




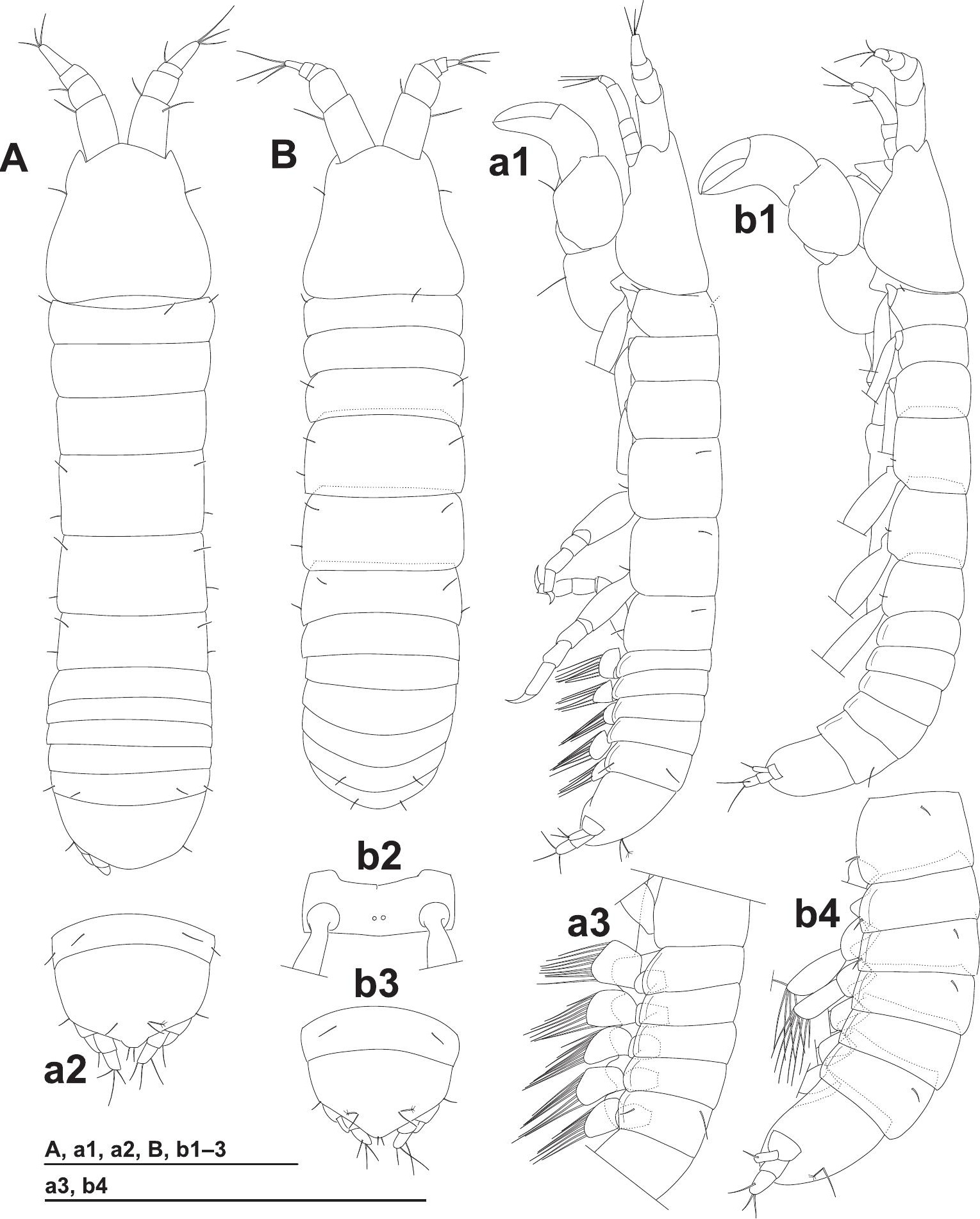




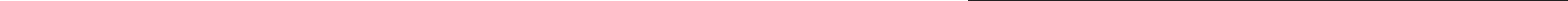




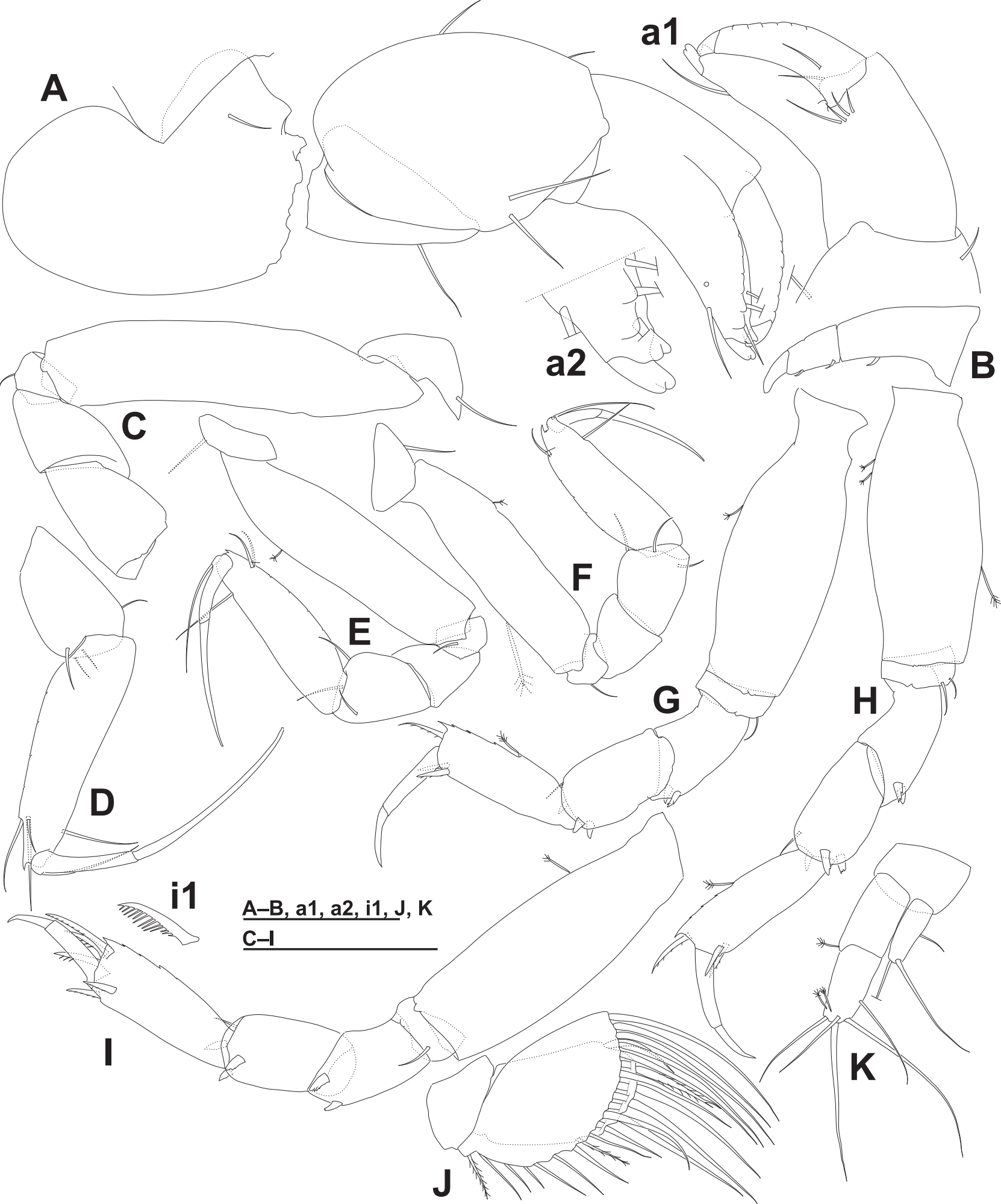




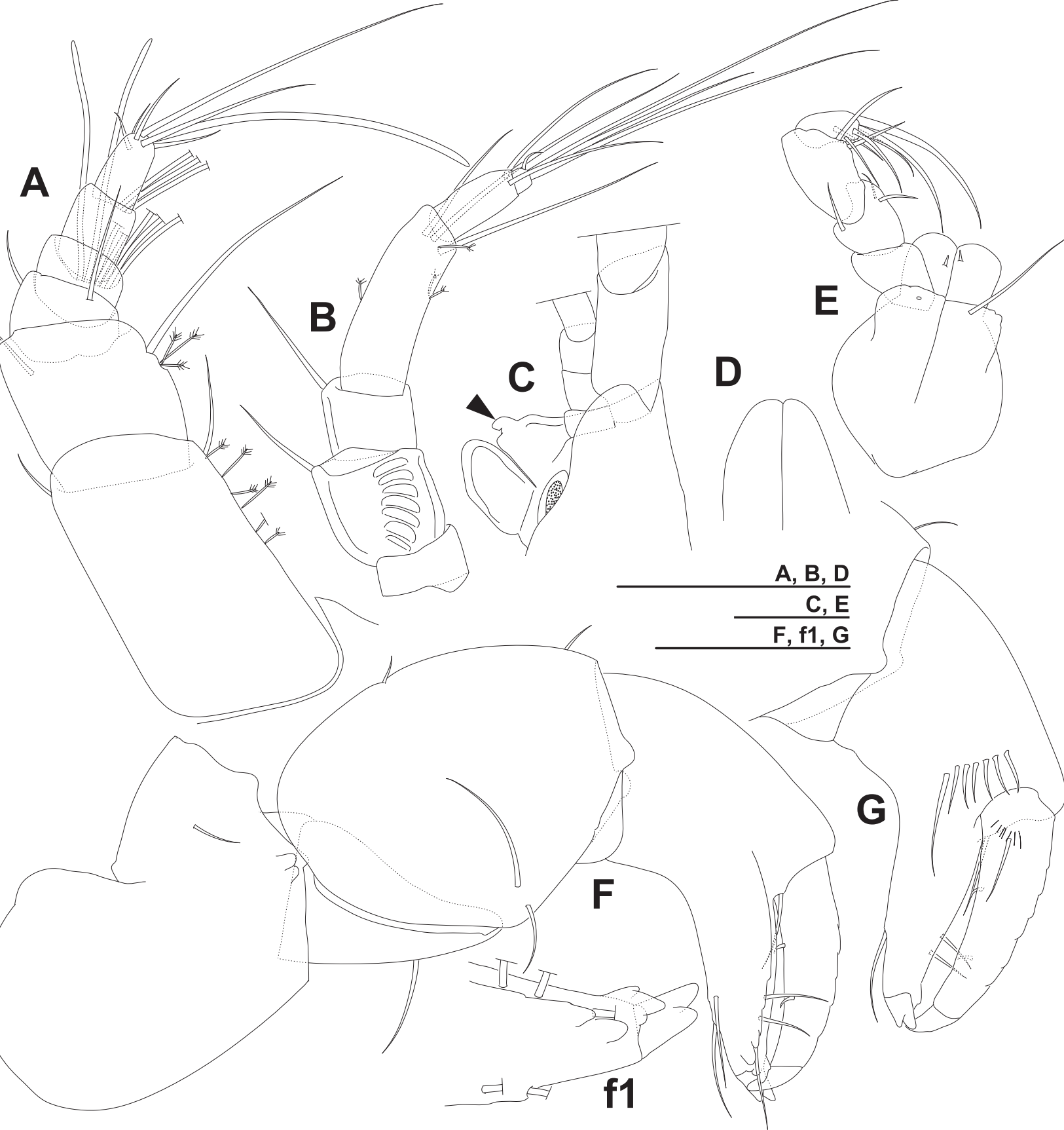




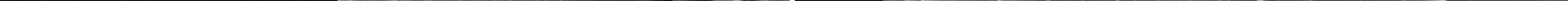




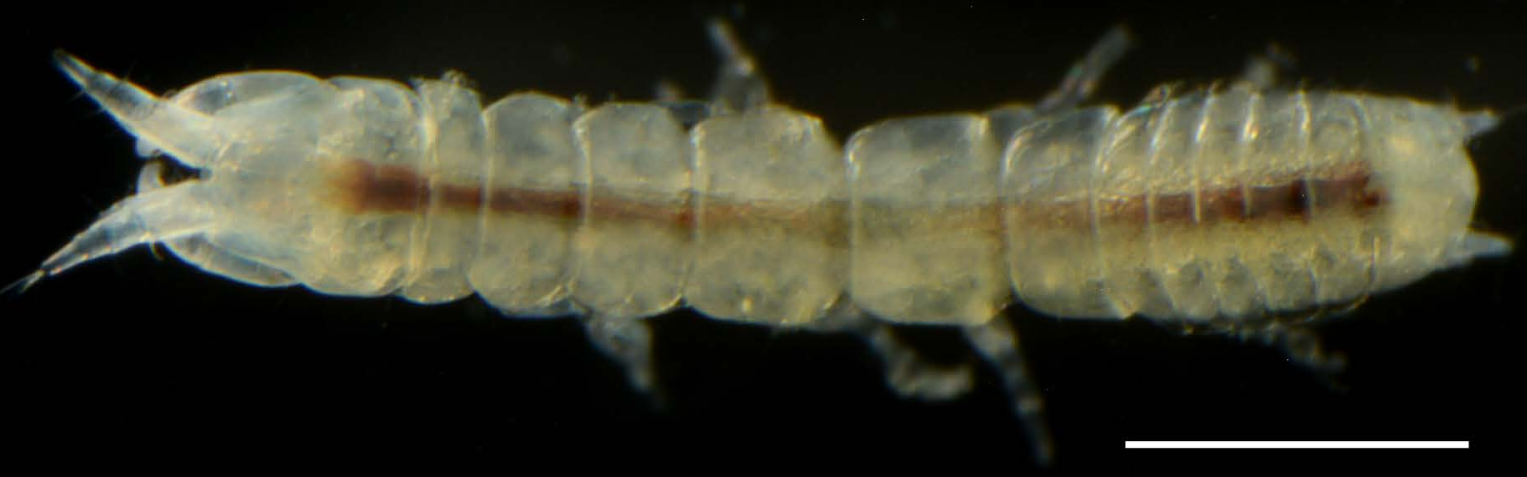

